\title{
Pembelajaran Pembukuan dalam Meningkatkan Pendapatan Bagi Pelaku Wirausaha Mikro
}

\author{
Arniati $^{1 *}$, Muryani Arsal ${ }^{1}$, Muhammad Rusydi ${ }^{1}$, Andi Arifwangsa Adiningrat ${ }^{1}$ \\ ${ }^{1}$ Program Studi Ekonomi Pembangunan, Fakultas Ekonomi dan Bisnis, Universitas Muhammadiyah Makassar, Jalan \\ Sultan Alauddin No. 259. Makassar, Indonesia Kode Pos 92330 \\ *Email koresponden: arniati@unismuh.ac.id
}

\section{ARTICLE INFO \\ Article history \\ Received: 08 Sep 2020 \\ Accepted: 03 Apr 2021 \\ Published: 23 Apr 2021 \\ Kata kunci: \\ Pembelajaran \\ Pembukuan \\ Wirausahawan mikro}

\begin{abstract}
A B S T R A K
Background: Latar belakang dilakukan kegiatan PKM adalah rendahnya pemahaman pembuatan laporaan keuangan yang baik dan benar serta pengelolaan laporan keuangan yang belum optimal. Tujuan kegiatan yaitu agar pelaku wirausaha dapat menyusun laporan keuangan yang baik dan benar yang dapat menjadikan usahanya lebih berkembang dan lebih maju sehingga pendapatannya meningkat. Metode: Pada pengabdian tersebut, tim telah melaksanakan pembelajaran pembukuan bagi mitra Wirausaha Student Mall Universitas Muhammadiyah Makassar dengan jumlah peserta sebanyak 10 orang dengan metode pelaksanaan yaitu pelatihan, dan pendampingan pembuatan laporan keuangan. Hasil: Hasil kegiatan yaitu meningkatnya pengetahuan serta keterampilan wirausaha dalam membuat pembukuan sederhana yang baik dan benar. Kesimpulan: Dengan melalui pembelajaran pembukuan maka pengetahuan pelaku wirausaha meningkat dalam hal pembuatan laporan keuangan sehingga motivasinya meningkat dalam bekerja untuk memperoleh pendapatan yang maksimal.
\end{abstract}

\section{A B S T R A C T}

\section{Keywords:}

Bookkeeping

Learning

Micro entrepreneurs
Background: The lack of understanding of making good and correct financial reports and management of financial reports that are not yet optimal. The objective of the activity is that entrepreneurs can compile good and correct financial reports that can make their business more developed and more advanced so that their income increases. Methods: The name of the partner is Entrepreneurial Student Mall, University of Muhammadiyah Makassar with a total of 10 participants with the implementation method, namely training, and assistance in making financial reports. Results: The result of the activity is increased entrepreneurial knowledge and skills in making good and correct simple bookkeeping. Conclusion: The conclusion of the PKM activities is that through bookkeeping learning, the knowledge of actors increases in making financial reports so that their motivation increases in work.

() 2021 by authors. Lisensi Jurnal Solma, UHAMKA, Jakarta. Artikel ini bersifat open access yang didistribusikan di bawah syarat dan ketentuan Creative Commons Attribution (CC-BY) license.

\section{PENDAHULUAN}

Salah satu cara dalam peningkatan pendapatan masyarakat yaitu dengan melaksanakan wirausaha, karena dengan melakukan wirausaha akan membuat masyarakat menjadi sejahtera serta dengan wirausaha akan membuka kesempatan untuk dirinya sendiri serta meraih keuntungan dari kesempatan yang diciptakan tersebut. Oleh karena hakikat setiap usaha didirikan adalah untuk mencapai tujuan tertentu, di mana tujuan masing-masing usaha secara umum bisa dikatakan sama hanya prioritasnya yang berbeda, Permatasari (2015). 
Hal tersebut disebabkan Usaha Kecil Menengah (UKM) mampu bertahan dibandingkan dengan usaha besar lainnya yang cenderung mengalami keterpurukkan. Hal ini dibuktikan dengan semakin bertambahnya jumlah Usaha Kecil dan Menengah (UKM) pada tiap tahunnya, (Subur \& Muhammad, 2014). Tujuan paling utama pada sebuah usaha memperoleh keuntungan semaksimal mungkin, begitu pula pada para pelaku Usaha Kecil dan Menengah (UKM), mereka memiliki tujuan tertentu selain memperoleh keuntungan dari usahanya ini adalah bisa mengurangi tingkat pengangguran tenaga kerja, (Hasyim, 2013).

Dalam menjalankan kegiatan usahanya sering kali pengelola Usaha kecil dan Menengah (UKM) merasa kesulitan di dalam melaksanakan pencatatan terhadap apa yang terjadi pada operasional usahanya. Kesulitan tersebut menyangkut kegiatan serta penilaian atas hasil yang diperoleh pada tiap usahanya, (Dinnullah \& Fayeldi, 2017). Apalagi jika harus dilaksanakan pengukuran serta penilaian atas kegiatan yang terjadi dalam aktivitas usaha. Pencatatan dilaksanakan hanya menghitung selisih di antara uang yang masuk dengan uang yang keluar, tanpa melihat pengeluaran uang itu untuk atau dari alokasi aktivitas usaha atau non usaha, (Winarno et al., 2020). Kebanyakan pelaku Usaha Kecil dan Menengah (UKM) hanya menghitung harta yang dipunyai sebatas uang kas yang dipegang saja. Mereka tanpa memahami bahwa pengertian harta lebih luas dari sekedar uang kas, (Putra \& Kurniawati, 2012).

Kebanyakan wirausaha mikro atau Usaha kecil dan Menengah (UKM), mempunyai tingkat kelembagaan usaha yang hampir nol. Mereka telah berwirausaha dalam beberapa tahun, namun mereka belum mengalami perubahan yang sangat berarti, (Direktorat Pembinaan Kursus dan Kelembagaan, 2010). Laely (2016) yang menjelaskan bahwa faktor kendala dalam pengembangan UMKM berupa informasi keuangan. Memperhatikan konteks aktivitas mereka dalam mencari nafkah, perubahan seharusnya terjadi mengingat banyaknya waktu serta pengalaman yang mereka lalui. Masalah tersebut telah berlangsung sejak lama, di mana mayoritas penjual mengalami hal tersebut.

Pelaku wirausaha mikro yang ada di Student Mall Universitas Muhammadiyah Makassar mempunyai keterbatasan pemikiran mengenai pengelolaan keuangan serta sumber daya manusia (SDM) yang kurang memadai dalam penyusunan laporan keuangan sehingga pemilik wirausaha mikro belum mengelola usahanya secara benar serta sesuai standar yang berlaku, dengan demikian operasional wirausaha mikro tidak terkontrol dengan baik, hal tersebut menimbulkan keinginan pelaksana Pengabdian Kepada Masyarakat (PKM) untuk mencoba menerapkan penyusunan laporan keuangan pada pelaku wirausaha mikro ini dengan berbasis SAK ETAP yang diharapkan dapat memberikan kemudahan bagi UKM dalam melakukan penyusunan dan menyajikan suatu laporan keuangan (Andriyani, 2014).

Laporan keuangan tersebut diharapkan pelaku wirausaha mikro bisa mengevaluasi usahanya dan bisa memakai informasi dalam laporan keuangan ini sebagai dasar dalam pengambilan keputusan usahanya atau bisnisnya, Berdasarkan uraian yang tersebut di atas, maka bisa ditarik kesimpulan bahwa tiap wirausaha mikro harus mempunyai laporan keuangan serta bagi pelaku wirausaha yang berskala kecil telah terdapat SAK ETAP dalam rangka untuk mempermudah penyusunan laporan keuangannya, (Hapsari \& Hasanah, 2017). Target kegiatan yang diharapkan dalam kegiatan Pembelajaran Pembukuan Dalam Meningkatkan Pendapatan Bagi Pelaku Wirausaha Mikro di Universitas Muhammadiyah Makassar adalah mampu mengimplementasikan pembelajaran pembukuan dalam peningkatan pendapatan bagi para pelaku wirausaha mikro yang secara tepat serta berdaya saing, dengan lebih dahulu mengidentifikasi, menilai factor-faktor internal wirausaha dan faktor-faktor eksternal lingkungan yang mempengaruhi pada pelaku wirausaha mikro (Ardiana \& Subaaedi, 2010). 
Tujuan pembelajaran pembukuan dalam hal ini pelatihan dan pendampingan tentang metode pencatatan serta pembukuan keuangan yang secara sederhana yang baik serta benar adalah agar pelaku wirausaha mikro bisa mengetahui berapa banyak laba atau rugi secara pasti yang mereka dapatkan dan juga dapat mengetahui keadaan keuangan usahanya sehingga bisa dipergunakan dalam mengontrol hasil usahanya, (Dahlan et al., 2018). Dengan demikian, maka pelaku wirausaha mikro dapat menjadikan usahanya lebih berkembang dan lebih maju sehingga pelaku wirausaha mikro tersebut meningkat pendapatannya sehingga sejahtera. Pembelajaran pembukuan yang dilaksanakan atau dilakukan bisa bermanfaat pada suatu saat dibutuhkan atau diperlukan, diantaranya bila usahanya menjadi besar, maka pembukuan tersebut bisa dipakai dalam pengurusan pajak, pengajuan kredit dan lain sebagainya (Warren \& Reeve, 2014).

\section{MASALAH}

Permasalahan yang dihadapi oleh pelaku wirausaha mikro di Student Mall Universitas Muhammadiyah Makassar yaitu minimnya pemahaman tentang tata kelola usaha yang baik dan benar diantaranya system pembukuan yang belum sesuai dengan standar akuntansi yang berlaku. Hal ini juga masih kurangnya pembuatan pencacatan laporan keuangan yang sampai saat sekarang ini masih belum optimal, di mana masih banyak para pelaku wirausaha mikro yang mencampuradukkan atau menggabungkan yaitu antara keuangan rumah tangganya dengan keuangan usahanya.

Keadaan ini disebabkan oleh karena masalah internal yang dihadapi oleh pelaku wirausaha mikro diantaranya minimnya kualitas sumber daya manusia dalam hal manajemen dari segi jumlah dan juga belum meratanya tingkat keterampilan para pelaku wirausaha mikro tersebut terutama di bidang keuangan, penguasaan teknologi, serta lemahnya strategi keuangan yang dimiliki, serta terbatasnya akses wirausaha mikro pada penguasaan informasi yang kurang seimbang dan penguasaan teknologi yang kurang baik. Namun yang lebih utama yaitu minimnya antusiasme oleh diri sendiri untuk dapat lebih mahir dalam memahami pembukuan dalam pembuatan laporan keuangan, minimal dalam membuat laporan keuangan sederhana yang baik dan benar.

Solusi yang ditawarkan dalam permasalahan adalah menyusun laporan keuangan berdasarkan SAK ETAP ketetapan Ikatan Akuntan Indonesia (IAI) yang ditetapkan pada tanggal 17 Juli 2009. Standar ini dibuat bagi pelaku Usaha Kecil Menengah yang akan memakai prinsipprinsip laporan keuangan dalam menyediakan informasi mengenai posisi keuangan, laporan laba rugi dan lain-lain, (Ikatan Akuntan Indonesia, 2009).

\section{METODE PELAKSANAAN}

Metode pelaksanaan kegiatan dalam Pengabdian Kepada Masyarakat (PKM) di Student Mall Universitas Muhammadiyah Makassar yang diketuai oleh Siti Chaerani Djaya, S.Sos dengan jumlah peserta yaitu sebanyak 10 orang diawali dengan koodinasi dengan penanggung jawab Mitra yang dilanjutkan dengan rapat. Hal-hal penting disampaikan dalam rapat koordinasi yaitu mengenai pelatihan yang terstruktur dan pendampingan. Pelatihan mengenai hal-hal yang terkait dengan keberhasilan pelaku Wirausaha dapat dijelaskan secara detail sebagai berikut:

1) Pencarian informasii mengenai cara membuat laporan keuangan yang baik dan benar. Tahap ini diilaksanakan oleh penulis melalui berbagai sumber informasi seperti dari youtube, internet, face book, dan lain sebagainya

2) Persiapan tempat, bahan, alat, serta waktu.

3) Pelatihan, Pelatihan pembuatan pembukuan yaitu diajarkan cara membuat laporan laporan keuangan. 


\section{Cara Membuat Laporan Keuangan Usaha}

Wirausaha mikro di Student Mall adalah usaha yang bergerak dalam booth fashion, foto kopy, booth minuman dan snack, counter, dan bahan campuan yang pencatatan laporan keuangannya diperlukan setiap periode baik mingguan atau bulanan. Pencatatan pembukuan ini digunakan sebagai sarana bagi pemilik atau mitra untuk mengetahui keberlangsungan usahanya atau going concern di dalam usahanya. Pada saat awal kita memberikan perkenalan terlebih dahulu apa itu pembukuan dan laporan keuangan. Alur dimulai pada saat pembelian bahan untuk diproses yang semuanya masih ditulis oleh para pelaku mikro sendiri.

Laporan laba rugi (gambar 1.) akan disusun berdasarkan apa yang terjadi dilapangan, karena mayoritas atau rata-rata mitra masih memakai tenaga kerja dari keluarga mereka sendiri jadi terkadang mereka tidak mencatat berapa gaji yang harus dikeluarkan atau di bayarkan. Apabila pebisnis pemula, maka dapat membuat buku laba rugi yang sederhana supaya mudah dipahami. Sebab, buku yang berantakan akan mempersulit Anda dihari yang akan datang.

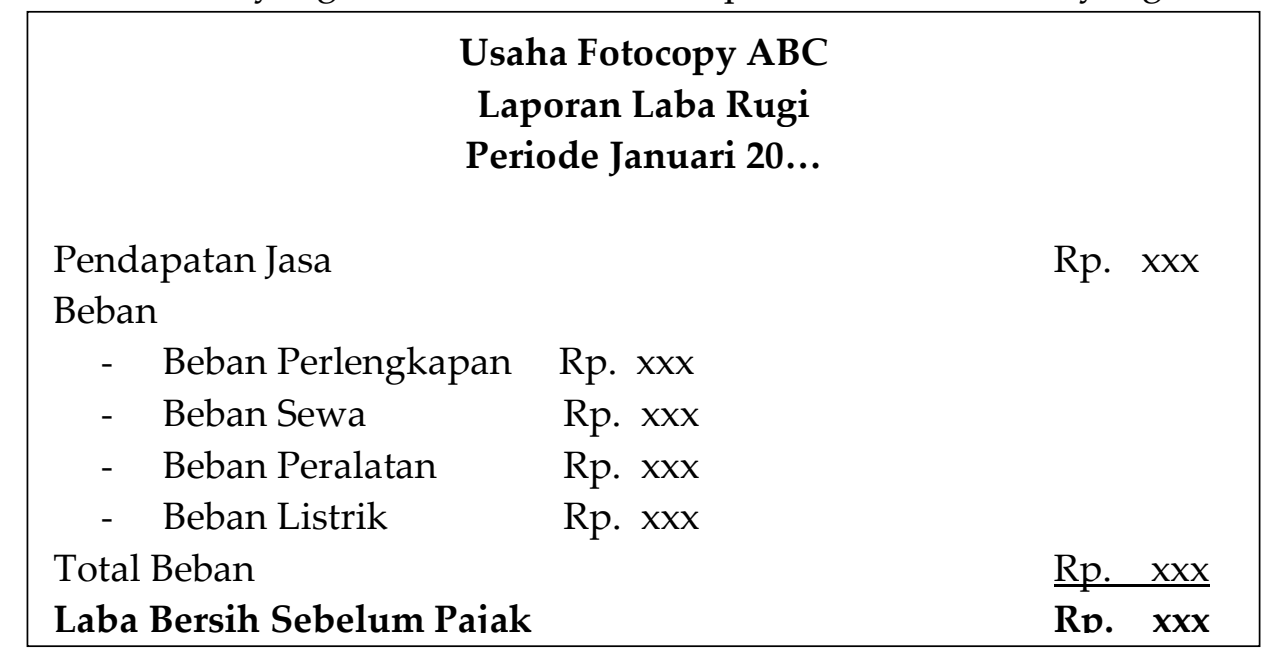

Gambar 1. Format Laba Rugi

Tabel 1. Neraca Usaha Jasa Fotocopy ABC per 31 Januari 2021

\begin{tabular}{|c|c|c|}
\hline AKTIVA & & PASSIVA \\
\hline Aktiva Lancar: & & Utang Lancar \\
\hline Kas & Rp. $X x x$ & Utang Usaha \\
\hline Perlengkapan & Rp. $X x x$ & \\
\hline Aktiva Tetap : & & Ekuitas \\
\hline Peralatan & Rp. $X_{x x}$ & Modal pemilik Rp. xxx \\
\hline Jumlah Aktiva & Rp. Xxx & Jumlah Utang dan Ekuitas Rp. Xxx \\
\hline
\end{tabular}

4) Sosialisasi

Sosialisasi dilakukan melalui sharing serta diskusi pada para pelaku wirausaha mikro dengan menyampaikan atau memberikan informasi dan pengetahuan mengenai manajemen keuangan. Materi yang disampaikan atau diberikan yaitu tentang bagaimana pengelolaan manajemen keuangan dalam hal tersebut yaitu cara membuat suatu pencatatan atau pembukuan yang sederhana yang baik dan benar untuk wirausaha mikro yang dijalankan, diantaranya sebagai berikut:

a. Membuat catatan pengeluaran 
Untuk memulai usaha, yang penting dilaksanakan yaitu membuat buku catatan terpisah dengan mencatat pengeluaran pembelian bahan bakunya, biaya operasionalnya, serta honor karyawan yang dicatat pada satu tabel dengan jelas (Wardiningsih et al., 2020). Dengan demikian, maka Andapun bisa lebih tahu tentang besarnya suatu modal usaha yang sudah dikeluarkan. Jika sudah, maka Anda dapat menetapkan target dan strategi supaya modal Anda dapat Kembali.

b. Membuat catatan pemasukan

Setelah catatan pengeluaran telah dibuat, selanjutnya Anda membuat catatan pemasukan pada buku terpisah. Buku tersebut dipakai dalam mencatat berbagai jenis pemasukan secara kontinyu setiap hari, misalnya penjualan produk atau jasa dan penerimaan piutang.

c. Membuat buku kas utama, yaitu menggabungkan antara buku kas pengeluaran dengan buku kas pemasukan agar diketahui keuntungan dan kerugian. Buku kas utama juga berperan penting dalam membuat perencanaan serta strategi bila usaha mempunyai biaya yang tak terduga.

d. Membuat buku stok barang, catatlah secara rutin barang yang masuk dan barang yang keluar setiap hari. Semakin banyak penjualan maka semakin banyak pula jumlah barang yang keluar masuk. Pencatatan stok barang akan memudahkan dalam mengawasi dan memonitor persediaan barang pada usaha.

e. Membuat buku inventaris, mencatat pembelian barang inventaris untuk mempermudah dalam pengawasan asset dan mencegah barang agar tidak mudah hilang.

f. Membuat buku laba rugi, mencatat pendapatan serta biaya dalam satu periode tertentu untuk memantau usaha apakah mendapat keuntungan atau justru kerugian serta dapat mengevaluasi strategi usaha, (Maulani. \& Saptina, 2016).

5) Pendampingan

Pada pendampingan tersebut akan diaplikasikan materi dalam hal perbaikan administrasi, pemasaran dan peningkatan nilai produk atau jasa yang mereka jual. Pengembangan produk atau jasa bertujuan untuk melaksanakan perbaikan dari sisi produk yang dijual yaitu mulai dari peningkatan kualitas ataupun harga jual dipasaran. Dari sisi jasa yaitu memperhatikan bagaimana wirausaha mikro beertinteraksi dengan wirausaha mikro lainnya, pembukaan jasa penjualan melalui pemesanana apabila dimungkinkan (Rakhmawati, 2018).

\section{HASIL DAN PEMBAHASAN}

Hasil yang didapatkan pada pembelajaran pembukuan sederhana bagi pelaku wirausaha mikro di Student Mall Universitas Muhammadiyah Makassar adalah para pelaku mempunyai pengetahuan dan keterampilan untuk memisahkan keuangan pribadi dengan keuangan usahanya, dan pelaku wirausaha mikro bisa mengetahui perkembangan mengenai usahanya dengan pembukuan yang baik dan benar serta sistematis. Aribawa (2016) menyatakan bahwa manajemen keuangan dalam hal menjalankan usaha adalah suatu aspek yang sangat penting untuk menentukan kemajuan suatu usahanya. Sehingga dengan manajemen yang baik maka diperoleh keuntungan yang jelas serta akan menjadi pengambilan keputusan yang tepat.

Dengan demikian, maka laporan pembukuan yang sederhana penting diterapkan dan diperlukan oleh para pelaku wirausaha mikro serta tidak menggabungkan antara uang pribadi dengan keuangan hasil usahanya. Hal tersebut menurut Maulani. \& Saptina (2016) yang menjelaskan bahwa dengan manajemen keuangan wirausaha kecil pada dasarnya akan tidak terlepas oleh fungsi-fungsi manajemen itu sendiri diantaranya kegiatan perencanaan (planning), pengorganisasian (organizing), pengalokasian (actuating) dan pengendalian (controlling). 
Menurut Rivai (2013) bahwa pencatatan pada laporan keuangan yang baik dan benar serta sistematis mempunyai manfaat, yaitu bisa memberikan informasi tentang kas yang bisa dipercaya mengenai keadaan keuangan usaha, bisa memberikan informasi keuangan tentang hasil usaha pada periode akuntansi, bisa memberikan informasi bagi pihak yang berkepentingan dalam menilai keadaan dan potensi usaha dan bisa memberikan informasi yang relevan pada pihakpihak yang berkepentingan.

Dengan demikian, maka pembelajaran pembukuan akan berpengaruh dalam perkembangan usahanya sehinga bisa mengetahui antara laporan pengeluaran serta pendapatannya. Selain itu juga, meningkatnya pengetahuan mengenai pentingnya mengelola suatu keuangan usahanya serta merencanakan keuangan supaya bisa meminimalkan suatu kerugian diakibatkan atas kesalahan sendiri. Dengan keuangan telah terkelola dengan baik dan benar diharapkan keuntungan usaha dapat meningkat serta dapat mengembangkan usahanya dimasa yang akan datang.

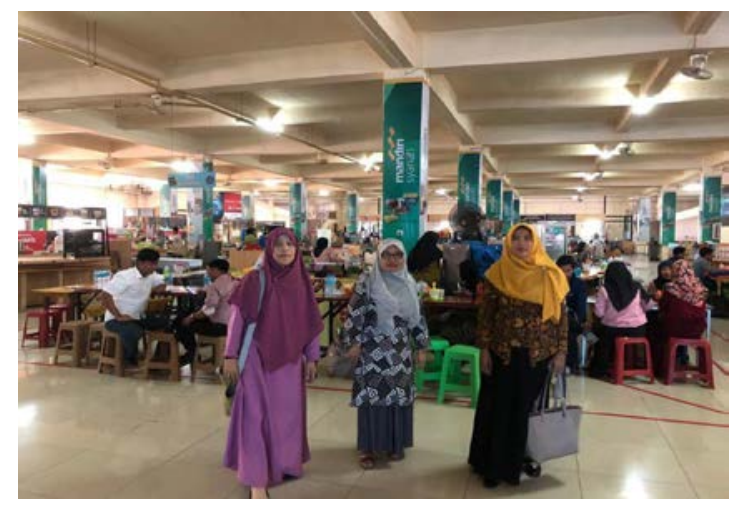

Gambar 2. Sebelum pelaksanaan kegiatan

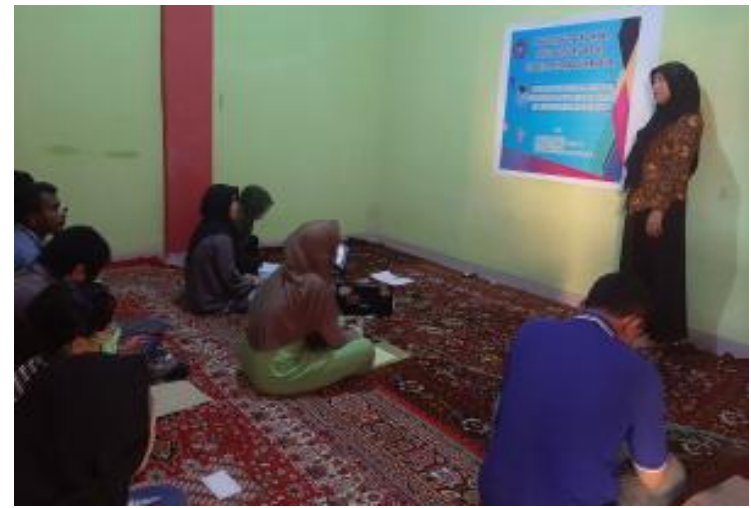

Gambar 3. Pelaksanaan Kegiatan

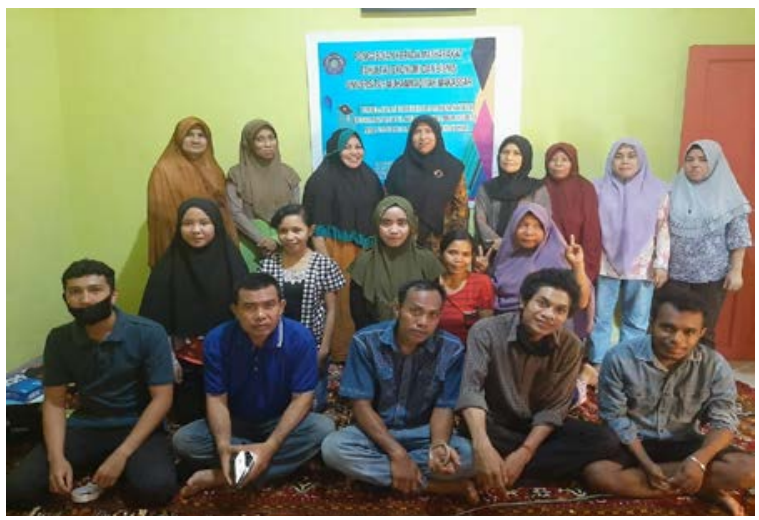

Gambar 4. Foto Bersama setelah Pelaksanaan Kegiatan

Dalam pembelajaran pembukuan bagi pelaku wirausaha mikro terlebih dahulu dijelaskan tentang pengenalan istilah yang ada dalam akuntansi. Selanjutnya dijelaskan tentang cara membuat laporan keuangan yang sederhana baik dan benar dengan membuat laporan arus kas, mencatat uang masuk yang diperoleh dari hasil penjualan serta uang keluar dalam membeli bahan baku yang berdasarkan bukti-bukti atau bon-bon yang telah diterima untuk diklasifikasikan yang berdasarkan jenis-jenis bahan baku yang telah dibeli.

Materi yang telah disiapkan pada pembelajaran pembukuan, yaitu, a) Pembukuan keuangan yang sederhana secara umum yang menjelaskan bahwa pembukuan sangat penting bagi pelaku wirausaha mikro dengan memisahkan keuangan pribadi dengan keuangan usaha supaya pelaku wirausaha dengan mudah untuk menganalisis hasil usahanya; b) Laporan keuangan arus kas menjelaskan mengenai jumlah penerimaan dan pengeluaran usaha dalam satu tahun serta 
sumber-sumbernya, c) Laporan keuangan laba rugi dengan informasi mengenai kegiatan usaha diantaranya hasil penjualan, biaya-biaya, serta laba/rugi.; d) Laporan perubahan modal yaitu untuk menggambarkan tentang peningkatan serta penurunan kekayaan bersih selama satu tahun yang berdasarkan prinsip pengukuran tertentu.; e) Neraca yang menjelaskan nilai-nilai aset, kewajiban/utang serta modal perusahaan dalam tanggal tertentu; f) Penerapan materi dalam soalsoal kasus wirausaha. Selain itu, kegiatan pembelajaran pembukuan tersebut tidak hanya searah, akan tetapi terjadi dua arah yaitu dalam sesi diskusi/tanya jawab. Diskusi/tanya jawab berlangsung sesudah penyampaian materi dengan tertib dan terarah.

Manfaat kegiatan pengabdian kepada masyarakat melalui pembelajaran pembukuan sederhana adalah pelaku wirausaha Student Mall bisa mengelola pembukuan keuangan wirausaha dengan baik, benar serta sistematis, sehingga bisa memperoleh laporan keuangan yang sesusai standar yang berlaku, untuk membantu kelancaran bantuan oleh pihak ketiga yaitu Bank yang akhirnya bisa membangun kekuatan wirausaha sehingga dapat tercapai kesejahteraan para pelaku wirausaha mikro yang secara adil serta merata. Selain itu, penerapan pembukuan sederhana yang baik dan benar juga bisa menciptakan budaya disiplin pada wirausahanya.

Berdasarkan hasil Pengabdian Kepada Masyarakat oleh pembelajaran pembukuan sederhana yang baik dan benar adalah memberikan respon yang positif terhadap pelaku wirausaha Student Mall serta para pelaku sangat antusias terhadap pembelajaran pembukuan.

Tabel 2. Ketercapaian Pengabdian Kepada Masyarakat

No. Pernyataan Respon

Dapat berpartisiipasi aktif melalui Pembelajaran

1. Pembukuandalam hal Pembuatan laporan keuangan dan Mengaplikasikannya

Menumbuhkan sikap kemandirian dan kualitas

2. hidup bagi pelaku wirausaha mikro di Student Mall sehingga pendapatannya bertambah dan kesejahteraan mereka meningkat.

Pendampingan dan keberlanjutan pengembanngnan 3. usaha produk oleh pihak PKM perguruan tinggi Universitas Muhammadiyah Makassar.
Pelaku Wirausaha mikrotermotivasi / terdorong untuk dapat berpartisipasi aktif melalui pembelajaran pembukuan.

Tumbuhnya sikap mandiri

Pelaku Wirausaha Mikro mampu Mengembangkan usahanya setelah diadakan pendampingan

Melalui pembelajaran pembukuan tersebut dapat meningkatkan pengetahuan serta keterampilan wirausaha mikro untuk membuat pembukuan sederhana yang baik dan benar, sehingga meningkatkan motivasi untuk bekerja (Wafirotin \& Sumarsono, 2016). Selain itu, Tim pengabdian Universitas Muhammadiyah Makassar akan melaksanakan tindak lanjut pembelajaran dengan melaksanakan monitoring untuk keberlanjutan kegiatan tersebut. Pelatihan tersebut sejalan dengan kegiatan. Tidak menutup kemungkinan yang akan datang bukan hanya mempunyai laporan keuangan manual yang sederhana, namun tim juga membantu mereka dalam membuat sistem laporan keuangan yang komputerisasi untuk memudahkan mereka.

\section{KESIMPULAN}

Kegiatan PKM melalui pembelajaran pembukuan sederhana yang baik dan benar serta sistematis bagi pelaku wirausaha Student Mall Universitas Muhammadiyah Makassar yang 
memberikan konstribusi yang sangat baik untuk pengembangaan wirausahanya. Kegiatan pengabdian tersebut memperoleh respon positif serta pelaku wirausaha memperoleh pengetahuan serta keterampilan tentang wawasan yang baru untuk menjalankan usahanya melalui pembukuan atau pencatatan keuangan sederhana agar mudah diaplikasikan. Implikasi kegiatan PKM melalui pembelajaran pembukuan sederhana adalah pelaku wirausaha mikro mampu memahamii cara berwirausaha secara baik melalui pencatatan keuangan untuk memudahkannya dalam menegetahui perkembangan wirausahanya.

\section{UCAPAN TERIMA KASIH}

Penulis mengucapkan terima kasih yang tak terhingga kepada LP3M Universitas Muhammadiyah Makassar yang telah memberikan dana Hibah PKM (Pengabdian Kepada Masyarakat) tahun 2020 dalam pelaksanaan program kegiatan tersebut dan telah memberikan masukan serta motivasi dalam pelaksanaan program PKM tersebut.

\section{DAFTAR PUSTAKA}

Andriyani, L. (2014). Analisis penerapan pencatatan keuangan berbasis SAK ETAP pada Usaha mikro kecil dan menengah (UMKM) (sebuah studi Intrepetatif pada usaha peggy salon). Jurnal Program Akuntansi S1.

Ardiana, \& Subaaedi, B. (2010). Kompetensi SDM UKM dan Pengaruhnya Terhadap Kinerja UKM di Surabaya. Jurnal Manajemen Dan Kewirausahaan, 12(1), 42-55. https://doi.org/10.9744/jmk.12.1.pp.42-55

Aribawa, D. (2016). Pengaruh Literasi Keuangan Terhadap Kinerja Dan Keberlangsungan Umkm Di Jawa Tengah. . Journal Siasat Bisnis, 20(1), 1-13.

Dahlan, T., Murfiah, U., \& Indriani, R. (2018). Pelatihan Pembukuan Sederhana bagi UKM Kerajinan Anyam Pandan di Kecamatan Rajapolah Tasikmalaya. Jurnal Solma, 7(2), 153-160.

Dinnullah, R. N. I., \& Fayeldi, T. (2017). Pelatihan Pembukuan Sederhana Usaha Rumah Tangga Susu Kedelai Bugul Lor. JPM (Jurnal Pemberdayaan Masyarakat), 2(1), 90-96. https://doi.org/https://doi.org/10.21067/jpm.v2i1.1744

Direktorat Pembinaan Kursus dan Kelembagaan, D. P. K. dan K. (2010). Manajemen Usaha Kecil. Direktorat Jendral Pendidikan Non Formal dan Informal Kementerian Pendidikan Nasional.

Hapsari, D. ., \& Hasanah, A. N. (2017). Model Pembukuan Sederhana Bagi UsahaMikro Di Kecamatan Kramatwatu Kabupaten Serang. Jurnal Akuntasi, 4(2), 36.

Hasyim, D. (2013). Kualitas Manajemen Keuangan Usaha Mikro Kecil Menengah (Umkm) (Studi Kasus Pada Distribution Store (Distro) Di Kota Medan). Jurnal Jupiis, 5(2).

Ikatan Akuntan Indonesia, I. (2009). Standar Akuntansi Keuangan Entitas Tanpa Akuntabilitas Publik Jakarta.

Laely, N. (2016). Penerapan Penyusunan Laporan Keuangan Pada Usaha Kecil Menengah Berdasarkan SAK EMKM di Surabaya. Jurnal STIE PERBANAS.

Maulani., \& Saptina, T. (2016). Pelatihan Pembukuan Keuangan Sederhana dan Motivasi Kewirausahaan pada Kelompok Usaha Makanan RW 02 Kelurahan Neglasari Kecamatan Cibeunying Kaler Bandung. Jurnal Dharma Bhakti STIE Ekuitas, 1(1), 33.

Permatasari, N. (2015). Analisis Penerapan Akuntansi Pada UMKM di Kelurahan Drajat Kecamatan Kesambi Kota Cirebon. Journal of Applied Microbiology, 119(3).

Putra, H. A., \& Kurniawati, E. P. (2012). Penyusunan Laporan Keuangan Untuk Usaha Kecil dan Menengah (UKM) Berbasis Standar Akuntansi Keuangan Entitas Tanpa Akuntabilitas Publik (SAK ETAP). Universitas 
Negeri Semarang.

Rakhmawati, I. (2018). Pengembangan Model Pelatihan Akuntansi Dalam Upaya Meningkatkan Kompetensi Keuangan Pada Umkm Wirausahawan Muda [IAIN Kudus]. In BISNIS : Jurnal Bisnis dan Manajemen Islam (Vol. 6, Issue 1). https://doi.org/10.21043/bisnis.v6i1.3569

Rivai, V. (2013). Commerical Bank Management: Manajemen Perbankan dan Teori ke Praktik (1st ed.). Rajawali Pers.

Subur, R. S., \& Muhammad, H. (2014). Pelatihan Manajemen Keuangan pada pelaku Usaha Toko Kelontongan Dusun Puluhan Desa Banyusidi Pakis Magelang Jawa Tengah. Jurnal Inovasi Dan Kewirausahaan, 3(2), 139.

Wafirotin, \& Sumarsono. (2016). Pengembangan Model Pelatihan Akuntansi dalam Upaya Peningkatan Kompetensi Keuangan pada Pelaku Usaha Mikro,Kecil dan Menengah (UMKM). PROSIDING SEMINAR NASIONAL HASIL-HASIL PENELITIAN 2016: BIDANG AGAMA ISLAM, BUDAYA, EKONOMI, SOSIAL HUMANIORA, TEKNOLOGI, KESEHATAN, DAN PENDIDIKAN, 45-55.

Wardiningsih, R., Wahyuningsih, B. Y., Sugianto, R., \& Mataram, U. T. (2020). Pelatihan Pembukuan Sederhana Bagi Pelaku Usaha Kecil ( Mikro ) Di Dusun Bore Desa Kopang. Jurnal Pendidikan Dan Ilmu Sosial, 2, 163-172.

Warren, C., \& Reeve, J. M. (2014). Pengantar Akuntansi. Salemba Humanika.

Winarno, A., Agustina, Y., Wijijayanti, T., Churiyah, M., \& Subagyo, S. (2020). Pelatihan Manajemen dan Pembukuan Dasar Bagi IKM Sanan Kota Malang. Jurnal Karinov, 3(1). 